DOI: $10.17951 / \operatorname{lrp} .2020 .39 .2 .39-50$

\author{
KAZIMIERZ CZerwiŃsKi \\ Uniwersytet Kazimierza Wielkiego w Bydgoszczy \\ ORCID - 0000-0002-0486-4370
}

\title{
DOBRO WSPÓLNE JAKO KATEGORIA PEDAGOGICZNA
}

\begin{abstract}
Streszczenie: Dobro wspólne jest kategorią z obszaru filozofii politycznej, niedocenianą przez liberalizm, bardzo ważną zaś dla tradycji republikańskiej. Ta kategoria jest problematyczna, ponieważ są trudności z jej zdefiniowaniem i ustaleniem zakresu. Autor stawia tezę, że dobro wspólne - niezależnie od kontrowersji, jakie wzbudza w filozofii politycznej - jest kategorią ważną dla refleksji pedagogicznej, a jednocześnie kategorią nieobecną. Uzasadnienia tej tezy skupiają się na dwu zagadnieniach: 1) cele edukacji są zorientowane neoliberalnie i kategoria dobra wspólnego jest w nich prawie nieobecna, co jest bardzo niepożądane w kontekście kształtowania obywateli demokratycznej wspólnoty; 2) procesy zachodzące we wnętrzu edukacji również nie sprzyjają myśleniu w kategoriach dobra wspólnego, głównie z powodu przewagi rywalizacji nad kooperacją oraz wadliwej komunikacji międzyludzkiej.
\end{abstract}

Słowa kluczowe: dobro wspólne, demokracja, edukacja, komunikacja

\section{WPROWADZENIE}

Dobro wspólne to jedna $\mathrm{z}$ ważnych, chociaż wysoce kontrowersyjnych, kategorii z obszaru filozofii politycznej. Kontrowersje powstają zarówno z powodu trudności ze zdefiniowaniem dobra wspólnego, jak i z różnic poglądów co do możliwości jego efektywnego uzgodnienia; przez niektórych teoretyków poddawana jest nawet w wątpliwość jakakolwiek przydatność tej kategorii. Uznając, że ta kategoria jest teoretycznie przydatna w obszarze filozofii politycznej, uważam również, że może ona być traktowana jako istotna dla współczesnej refleksji pedagogicznej. Po przybliżeniu najważniejszych ustaleń dotyczących tego pojęcia, a zawartych w tekstach filozoficznych, przystąpię do próby uargumentowania mojej tezy. 


\section{KONTROWERSJE WOKÓŁ DOBRA WSPÓLNEGO}

Dobro wspólne to kategoria, której (pra)początków można poszukiwać już u filozofów starożytnej Grecji, ale przede wszystkim w Rzymie. Na przykład dla Cycerona owo dobro było rozumiane głównie jako dobro res publica i wszelkie działania władców miały być o tyle właściwe, o ile służyły dobru republiki, w drugiej kolejności zaś - dobru obywateli (zob. Koperek 2004, s. 139). Takie wzajemne usytuowanie dobra osobistego i dobra publicznego, z nadrzędnością tego ostatniego, jest zresztą charakterystyczne dla - wyrosłej z ducha rzymskiego, ale również współcześnie kultywowanej - tradycji republikańskiej; obywatel, pojmowany w duchu republikańskim, powinien być gotów, jeśli zajdzie taka potrzeba, postawić wyżej dobro republiki nad własną pomyślnością (zob. np. Szymczyk 2012, s. 111-152). Kategoria dobra wspólnego była obecna również u różnych myślicieli chrześcijańskich, znajdując najbardziej rozwiniętą filozoficznie postać u Tomasza z Akwinu. Tomasz wprowadził dwa jego rozumienia: 1) ogólne - dotyczące całości bytu; 2) ścisłe - dotyczące konkretnych społeczności ludzkich (zob. Koperek 2004, s. 139); oczywiście tylko to drugie pojmowanie znalazło kontynuację w obszarach filozofii politycznej i różnych nauk społecznych.

W powyższych ujęciach dobro wspólne jest definiowane i narzucane z zewnątrz - przez władcę danego organizmu politycznego, jak na przykład u Cycerona, bądź przez Boga, jak u Tomasza. W rezultacie antyczne i średniowieczne pojmowanie dobra wspólnego okazuje się mało przydatne we współczesnych społeczeństwach rządzących się w sposób demokratyczny, w których nie tylko formalna władza jest wyłaniana oddolnie, lecz również w wyniku nieskrępowanej publicznej debaty ustalane są cele wszelkiego działania zbiorowego. W społeczeństwach demokratycznych pojawił się więc również problem zdefiniowania dobra wspólnego, jak też ustalenia zakresu, czyli dookreślenia, co jest, a co nie jest dobrem wspólnym. Warto przeanalizować choćby kilka wybranych stanowisk.

Kazimierz Dziubka, Bogdan Szlachta i Lech Nijakowski następująco - dosyć abstrakcyjnie - definiują dobro wspólne: „Termin oznaczający wartość zbiorową osiąganą przez wspólnoty ludzkie w związku z rozwijaniem naturalnych możliwości ich członków, zaspokajaniem ich indywidualnych interesów lub respektowaniem posiadanych przez nich uprawnień jednostkowych przy jednoczesnej dbałości o zbliżanie całej wspólnoty ku właściwym jej celom” (Dziubka, Szlachta, Nijakowski 2008, s. 48). Zwraca uwagę - charakterystyczne dla myślenia liberalnego, a odwrotnie niż w myśleniu republikańskim - pojmowanie dobra wspólnego jako w pewien sposób „wtórnego” wobec owych indywidualnych interesów czy uprawnień jednostkowych. Łatwo w tym ujęciu dostrzec koncepcję umowy społecznej przekonania, że „jednostka wyprzedza państwo”, które powstaje tylko dlatego, że 
jednostki dobrowolnie pozbywają się części swych uprawnień w zamian za ochronę jednostkowych interesów. W niektórych radykalnych stanowiskach liberalnych dobro wspólne jest traktowane jako termin niepożądany, a w każdym razie pusty, niemający żadnej treściowej zawartości - ze względu na niemożliwość uzgodnienia, co owym dobrem wspólnym jest w sytuacji, gdy ,jednostkowe preferencje są same w sobie usprawiedliwione", gdy trudno o wspólną wszystkim ludziom hierarchię dóbr i wartości, gdy swoistym fetyszem jest neutralność światopoglądowa i ideologiczna państwa (zob. Dziubka, Szlachta, Nijakowski 2008, s. 48-49).

Jeśli zaś nawet nie jest to termin pozbawiony znaczenia, to często spotyka się akcentowanie jego sensu materialnego. Przykładem jest oksfordzki Słownik socjologii i nauk społecznych, który używa (prawie zamiennie) terminów „dobro publiczne” i „dobro zbiorowe”, pojmując je w niemal czysto ekonomiczny sposób, jako „takie, którego konsumpcja przez osobę $A$ nie kłóci się z konsumpcją przez osobę $B$ ”' (Marshall 2005, s. 57). Takie dobra mają trzy cechy: 1) „niewyłączalność” - która oznacza, że takiego dobra nie można nikogo pozbawić nawet wówczas, gdy nie zamierza za nie płacić, przykładem jest sygnalizacja świetlna; 2) „niemożliwość nieprzyjęcia” - która oznacza, że nie można odmówić „konsumpcji” takiego dobra, nawet gdy ktoś sobie go nie życzy, przykładami są systemy bezpieczeństwa publicznego czy obrony narodowej; 3) „niekonkurencyjność w konsumpcji” - oznaczająca niezależność kosztów danego dobra od liczby użytkowników, przykładem są publiczne stacje telewizyjne czy rozgłośnie radiowe (zob. Marshall 2005, s. 57). Do typowych dóbr publicznych są zaliczane: „obrona narodowa, bezpieczeństwo publiczne, oświata, służba zdrowia, straż pożarna i inne służby ratownicze, sieci telekomunikacyjne, drogi, kolej, przestrzeń powietrzna i służby transportu, ochrona narodowych pomników kultury i przyrody, wodociągi, radio i telewizja publiczna" (Marshall 2005, s. 58). Zapewne należałoby również dodać Internet; niezależnie od tego - na co zwracają również uwagę autorzy Słownika - trzeba podkreślić, że nie wszystkie wymienione wyżej dobra i nie zawsze są dobrami czysto publicznymi, czyli - w tej narracji - finansowanymi z pieniędzy publicznych, niektóre mają związek z rynkową konkurencją i zyskiem.

Jednakże rynkowo zorientowane myślenie liberalne - chociaż dominujące w licznych narracjach - nie jest jedynym. Tadeusz Buksiński, komentując poglądy francuskiego personalisty Jacquesa Maritaina, podkreśla, że - według tego myśliciela - celem wszelkiej polityki jest realizacja dobra wspólnego i następująco je dookreśla: „Dobro wspólne to całość pozytywnych wartości i dóbr wytworzonych przez członków danego społeczeństwa i służących ich życiu. [...] Dobro wspólne to cel polityki, a zarazem zasada organizacyjna społeczeństw" (Buksiński 2006, s. 126). Maritain wyróżnia trzy składniki dobra wspólnego: 1) dobra materialne, służące zaspokojeniu potrzeb biologicznych;2) dobra polityczne, m.in.: demokratyczny ustrój, udział we władzy, sprawiedliwe sądownictwo, porządek publiczny, 
bezpieczeństwo, tolerancja; 3) dobra duchowe „zapewniające godne życie, takie jak: docenianie moralności w życiu społecznym, oparcie go na prawdzie, stwarzanie warunków dla rozwoju osoby ludzkiej” (zob. Buksiński 2006, s. 126). Dosyć podobnie Jerzy Koperek - dokonując podsumowania poglądów różnych przedstawicieli katolickiej nauki społecznej, dla której ta kategoria ma bardzo duże znaczenie wyróżnia trzy „podstawowe elementy dobra wspólnego państwa”: 1) porządek społeczny i prawno-administracyjny; 2) całość dóbr materialnych; 3) zespół instytucji z dziedziny kultury, oświaty i wychowania, określany też przez autora zwięźle jako porządek kulturowy (zob. Koperek 2004, s. 144-146). Koperek podkreśla, że dobro wspólne musi być tak ujmowane, by stanowiło niezbędny warunek rozwoju każdej jednostki - to teza nader ważna z pedagogicznej perspektywy.

Amerykański filozof Michael Sandel, zaliczany do grona tzw. komunitarystów, toczących spór z liberalizmem, głównie o wzajemne usytuowanie jednostki i wspólnoty, proponuje „nową politykę dobra wspólnego”, która powinna przede wszystkim podejmować następujące tematy: 1) obywatelstwo, poświęcenie i służba; 2) moralne granice rynków; 3) nierówność, solidarność i cnota obywatelska; 4) polityka zaangażowania moralnego (zob. Sandel 2013, s. 355-362). Na temat tego ostatniego pisze: „Polityka zaangażowania moralnego jest nie tylko bardziej inspirująca od polityki uników, ale stanowi również bardziej obiecujący fundament sprawiedliwego społeczeństwa” (Sandel 2013, s. 362). W ten kontekst znakomicie wpisuje się taka oto myśl Józefa Tischnera: „Polityka to - w radykalnym znaczeniu tego słowa - nauka projektu, sensownego projektu dla ludzkich poświęceń na aktualnym etapie dziejów" (Tischner 2000, s. 493). Polityka i poświęcenie - to paradoksalne zestawienie może inspirować do niebanalnego namysłu nad istotą polityki, ale to temat dla (nieco) innych rozważań.

Tischner, w kontekście rozwijanej przezeń filozofii dialogu i chętnie posługujący się kategorią spotkania, następująco pisze o konieczności i możliwości wyjścia poza egocentryczny subiektywizm: „Podmiot myślący nie jest Ja osamotnionym, pogłębiającym swym myśleniem swoje osamotnienie. Przeciwnie, jest on subiektywnością, która poszukuje wspólnoty z drugim i świadczy o wspólnocie. [...] Idzie o to, by porzucić sytuację 'dla mnie' - 'dla ciebie' i przejść do sytuacji 'dla nas’. Aby mieć wspólny temat, trzeba osiągnąć wspólny punkt widzenia” (Tischner 2000, s. 466). I dalej: „Prawda o subiektywności jest więc taka: drugi jest we mnie, jest bliżej mnie niż ja sam siebie. Tylko dlatego, że drugi jest we mnie, że jest tak blisko, mogę pragnąć wspólnych punktów widzenia, pytania i odpowiadania, mówienia” (Tischner 2000, s. 467). Autor m.in. w ten sposób sposób uzasadniał, jak możliwe jest „wyjście z kryjówek”, jak możliwe jest spotkanie z drugim. Ale można tu również znaleźć interesujący przyczynek do rozważań nad trudną kwestią: jak w ogóle jest możliwe uzgodnienie dobra wspólnego. 
Kategoria dobra wspólnego funkcjonuje często jedynie na marginesach różnych dyskursów, na co zwraca uwagę np. Paweł Śpiewak. Wskazuje on pięć najważniejszych przyczyn takiego stanu rzeczy. Po pierwsze różnorodność rozumienia w różnych kulturach tego, czym jest dobre życie, uniemożliwia wskazanie jednolitego wzorca, do którego można by odnosić zarówno jednostkę, jak i politykę, co (rzekomo) implikuje konieczność redukcji tego pojęcia do indywidualnych koncepcji szczęścia każdej jednostki z osobna. Po drugie pojęcie dobra wspólnego zostało skompromitowane przez różne totalitaryzmy i autorytaryzmy, które się nim ochoczo posługiwały, „uszczęśliwiając” ludzi na siłę ponad ich głowami i wbrew ich potrzebom i interesom. Po trzecie koncepcja dobra wspólnego jest rzekomo zasadniczo nie do pogodzenia z demokracją, sugeruje bowiem, że coś, o niejasnym pochodzeniu i statusie, stoi ponad wolą ludu wyrażoną w głosowaniu. Po czwarte jest to kategoria nazbyt statyczna, jak dla potrzeb zmieniającego się coraz szybciej świata; raz w danej wspólnocie uzgodniona i wyartykułowana szybko się zdezaktualizuje. Po piąte kategoria dobra wspólnego jest nie do pogodzenia z liberalną koncepcją wolności, ponieważ wolność jest związana z „niepowtarzalnym rozumieniem siebie”, dobro wspólne zaś wymaga pewnej dozy rezygnacji z owej indywidualnej niepowtarzalności (zob. Śpiewak 1998, s. 5-6).

Dokonawszy takiej konstatacji autor próbuje jednak na dalszych kartach przywołanej książki obronić tę kategorię i sens posługiwania się nią również współcześnie. Ta obrona w znacznej mierze wiąże się z krytyką liberalizmu, lub przynajmniej różnych jego słabości, a jednocześnie ze swoistą promocją myślenia republikańskiego. Odwołuje się m.in. do arystotelesowskiej kategorii phronesis, pojmowanej jako roztropność danej wspólnoty politycznej, zbiór wewnętrznych i swoistych dla danej wspólnoty reguł racjonalności, dalekich jednak od ideologicznych, ściśle racjonalnych i niejednokrotnie przeintelektualizowanych konstruktów myślowych. Pisze: „[...] w przypadku wiedzy praktycznej poznanie tego, co jest dobrem, wyrasta ze sfery praktycznego doświadczenia” (Śpiewak 1998, s. 11) $\mathrm{i}$ „[...] phronesis jest cnotą, w której uobecniają się polityczna mądrość oraz długo zdobywane wiedza i doświadczenie" (Śpiewak 1998, s. 13).

Dobro wspólne może być odnoszone do różnie zakreślonych wspólnot, począwszy od globalnej, poprzez wspólnotę państwową, aż do wspólnot lokalnych, jak np. miasto czy gmina; możliwe jest również rozważanie tej kategorii wobec wspólnot określonych niekoniecznie w sposób terytorialny, lecz według innych kryteriów, np. zawodowych, hobbystycznych czy religijnych. Wówczas dobrem wspólnym będzie nie tylko np. nieskażone środowisko, bezpieczeństwo w miejscach publicznych, wolna sfera publiczna czy estetyka przestrzeni miejskiej, ale również istnienie danego zakładu pracy i jego obrona przed likwidacją, możliwość realizacji w jakimś stowarzyszeniu wspólnych zainteresowań i pasji czy wreszcie 
troska o zbawienie dusz członków danej wspólnoty religijnej - by ograniczyć się do przykładów ukierunkowanych raczej na wartości niż dobra materialne.

Dobro wspólne jest pojęciem podrzędnym do ogólniejszego pojęcia dobra. Ewa Albińska - przytoczywszy w bardzo dużym skrócie najważniejsze filozoficzne rozważania nad istotą dobra - przytacza również jego najważniejsze podziały: 1) ze względu na doskonałość można wyróżnić (a) dobro najwyższe, jakim jest np. Bóg czy określony ideał etyczny oraz (b) dobra częściowe, czyli byty „o ograniczonej doskonałości”; 2) ze względu na przedmiot rozróżnia się (a) dobra materialne i (b) dobra duchowe, jak świętość, cnota, wartości moralne i artystyczne itp.; 3) ze względu na podmiot rozróżnia się (a) dobra osobiste, np. zdrowie, wizerunek, wolność, swoboda sumienia oraz (b) dobra publiczne, inaczej właśnie dobra wspólne; 4) ze względu na faktyczną wartość można wyróżnić (a) dobra prawdziwe oraz (b) dobra pozorne, złudne, fałszywe (zob. Albińska 2009, s. 56). Te typologie warto tu przywołać, ponieważ - mimo że dychotomiczne, a więc raczej upraszczające zagadnienie - uwrażliwiają, że np. oprócz dobra absolutnego istnieje możliwość jego stopniowania, ale wskazują także na możliwość podążania za pozorami, nie tylko w indywidualnych dążeniach, lecz również w działaniach zbiorowych.

\section{PEDAGOGICZNE KONTEKSTY DOBRA WSPÓLNEGO}

Ale dlaczego ta - tak kłopotliwa teoretycznie i trudna w praktycznej realizacji kategoria dobra wspólnego miałaby mieć znaczenie dla pedagogicznej refleksji? Wskazałbym dwie grupy argumentów, które roboczo nazywam: 1) teleologicznym, 2) immanentnym. W pierwszym przypadku chodzi mi o cel edukacji, w drugim o „wnętrze" tej edukacji.

Ad 1. W wyniku dominacji w sferze publicznej narracji (neo)liberalnej, również cele oświaty są w ostatnich dziesięcioleciach formułowane w sposób zorientowany na indywidualny sukces, $\mathrm{w}$ tym również sukces rynkowy, na przedsiębiorczość, na skuteczność, do języka pedagogicznego zaś przedostały się takie właśnie terminy, jak owa skuteczność, efektywność, kosztochłonność, ale również obiektywność oceniania itp. Bardzo krytycznie o tym zjawisku i jego konsekwencjach piszą w znanej książce Eugenia Potulicka i Joanna Rutkowiak (2012).

Jeszcze krytyczniej Andrzej Olubiński charakteryzuje współczesne (raczej: ponowoczesne) oblicze społeczeństwa, gospodarki i edukacji - jako bytów powiązanych ze sobą różnymi więziami - używając m.in. terminów: „korporacyjna ekonomia”, „społeczeństwo neoliberalno-korporacyjne”, „sterowana przez biznes konsumpcyjno-fluktuacyjna demokracja" itp. Jako pedagog w swojej krytyce koncentruje się oczywiście na edukacji: „Celem oraz istotą kształcenia [...] jest 
programowy antyintelektualizm, obsesyjna dyscyplina, osobowości podporządkowane, zniewolone, zastraszone, niepewne jutra. [...] skuteczna edukacja to produkcja konsumenta oraz obywatela: automatów robiących odpowiednie zakupy oraz reagujących na demagogiczne hasła obywateli [...]. Edukacja efektywna i oszczędna musi być: uproszczona, krótkotrwała, praktycystyczna, infantylna, pasywna, antyintelektualna (najlepiej testowa i obiektywna), bezkrytyczna itd." (Olubiński 2016, s. 37-39). Przytaczając - za wspomnianymi wyżej autorkami „cele” edukacji neoliberalnej (kształtowanie: „ludzkich producentów”, „ludzkich konsumentów” i „ludzkich odpadów”) proponuje dodać - dotyczące kontekstu obywatelskiego - trzy kolejne orientacje: „[...] 'ludzcy klakierzy’ - bezkrytycznie oraz często bezmyślnie popierający oraz 'uzasadniający' każdą decyzję polityczną władzy; 'ludzkie marionetki' dające się bezwolnie sterować, manipulować oraz wykorzystywać dla doraźnych celów społeczno-ekonomicznych; 'ludzkie polityczne marginesy' - pomijani, lekceważeni, pomniejszani, deprecjonowani oraz na różne sposoby karani [...] za wyrażanie swoich odmiennych poglądów, postaw czy opinii" (Olubiński 2016, s. 40). Nawet jeśli autor w niektórych miejscach popada $\mathrm{w}$ przesadę, to warto $\mathrm{z}$ uwagą pochylić się nad tego typu analizami, ponieważ uczulają one na całkiem realne zagrożenia.

$\mathrm{Z}$ przekonujących analiz dokonywanych przez tych troje pedagogów wyłania się niepokojący obraz edukacji, która kształtuje (może kształtować) jednostkę skrajnie indywidualistyczną, zorientowaną na sukces rynkowy i konsumpcję, zupełnie nienastawioną na jakiekolwiek dobro wspólne. Można dodatkowo domniemywać, że tak ukształtowana jednostka nie stanie się takim obywatelem, jakiego potrzebuje demokratyczne społeczeństwo.

O tym, że oświata w niezadowalającym stopniu sprzyja kształceniu obywatela demokratycznej wspólnoty pisze oczywiście przede wszystkim Zbigniew Kwieciński - i to w bardzo licznych tekstach; warto wymienić pisane przed ponad dwudziestu laty, a wciąż aktualne, teksty tego autora, jak na przykład Kwieciński (1996; 1998). Z nowszych pozycji warto wymienić Kwieciński 2017. Oto próbka jego głosu: „Podzielam głębokie przekonanie tych humanistów polskich, którzy niejednokroć po gruntownych badaniach - twierdzą, że nie da się uratować szansy na wielką transformację Polski bez zasadniczo, radykalnie odmienionej edukacji publicznej dzieci, młodzieży i dorosłych. To wielkie przejście wymaga bowiem od większości, a nie mniejszości jak uprzednio, kompetencji do rozstrzygania trudnych dylematów (Sztompka, Bauman) i 'koordynacji sprzecznych interesów' (Reykowski), kompetencji do społecznego porozumiewania się w celu znajdowania kompromisów i konsensusu w uzgadnianiu zbiorowych celów, zamiast dotychczas narzucanej utopii" (Kwieciński 1998, s. 13). Potwierdzeniem alarmistycznych diagnoz i prognoz Kwiecińskiego jest - wyłaniający się z licznych badań - nader 
niepokojący obraz przeciętnego polskiego obywatela: z jednym $\mathrm{z}$ najniższych w Europie wskaźników tzw. uogólnionego zaufania, z najniższą w Europie frekwencją wyborczą, z jednym z najniższych wskaźników opisujących zrzeszanie się w organizacjach pozarządowych, $\mathrm{z}$ niską kulturą prawną, z bardzo niskim poziomem debaty publicznej itp. (zob. np. Przybyszewski 2013; Czapiński 2015, s. 332-372; Boguszewski 2018; Cybulska, Pankowski 2018 oraz wiele innych raportów i analiz). Wspólną praprzyczyną tych wszystkich negatywnych zjawisk wydaje się - oprócz zapewne jeszcze innych przyczyn - brak myślenia w kategoriach dobra wspólnego.

Pewne wycinkowe potwierdzenie można znaleźć również w prowadzonych przeze mnie badaniach. W okresie od stycznia do maja 2018 roku - w ramach pewnego dużego projektu badawczego - przeprowadziłem 18 wywiadów z działaczami politycznymi różnych szczebli (od posłów po wójtów i radnych gmin) i różnych opcji politycznych, a także z działaczami różnych organizacji pozarządowych (wśród badanych 7 osób należy jednocześnie do obu kategorii). Celem tych wywiadów była aktualna diagnoza deficytów obywatelskości w naszym kraju, jak również próba wskazania ich uwarunkowań. W znacznej mierze zostały potwierdzone - zasygnalizowane wyżej - deficyty obywatelskości opisywane w literaturze, w rozmowach pojawiło się jednak kilka dodatkowych elementów, a m.in.: 1) brak myślenia w kategoriach wspólnoty, nadmierna skłonność do rywalizacji i generowania konfliktów, postrzeganie przez przedstawicieli władz dobrowolnej aktywności obywatelskiej jako konkurencji, zagrożenia; ale też vice versa: zaangażowanie obywateli - jeśli w ogóle ma miejsce - najczęściej odbywa się na podstawie „więzi negatywnych", przeciwko komuś, zazwyczaj lokalnym władzom; 2) istnienie bardzo silnych lokalnych „układów”, grup interesu, wręcz sitw, które mogą ograniczać (i niejednokrotnie ograniczają) przejrzystość wielu działań społecznych, co wielu zniechęca do aktywności; jednocześnie: liczne przypadki nie zawsze szlachetnych pobudek, dla których (niektórzy) obywatele angażują się społecznie lub (zwłaszcza) politycznie, mówiąc krótko - interesowność; 3) podejrzliwość - nie zawsze uzasadniona - wielu obywateli wobec społeczników („na pewno mają w tym jakiś interes”).

Oczywiście nie za wszystkie te deficyty obywatelskości należy winić rodzimą edukację, zapewne niemały ładunek uwarunkowania tego stanu rzeczy można znaleźć w naszym dziedzictwie historycznym. Jednakowoż - jeśli stan rzeczy jest niezadowalający - edukacja jest od tego, by naprawiać. Kategoria dobra wspólnego wydaje się zaś zapoznana lub przynajmniej mało obecna wśród celów naszej edukacji, zamiast tego dominuje takie formułowanie celów kształcenia, które kładzie nacisk na indywidualną efektywność, na wiele sposobów atomizując uczniów, a w konsekwencji nie sprzyjając demokratycznej obywatelskości.

Ad 2. Dobro wspólne jest kategorią (prawie) nieobecną w procesach zachodzących wewnątrz polskiej edukacji, zwłaszcza oświaty. Oto głos młodej badaczki 
Olgi Napiontek: „Gdy jednak się przyglądamy, w jaki sposób na co dzień rozwijane są [...] umiejętności obywatelskie w szkołach, okazuje się, że uczniowie mają nauczyć się dyskutować, nie dyskutując, współpracować w grupie, pracując indywidualnie, egzekwować swoje prawa bez zrozumienia ich treści, samorządności bez możliwości podejmowania samodzielnych działań i bez wpływania na jakiekolwiek istotne decyzje, mają podejmować oddolne działania, realizując plan działań samorządu ustalony przez nauczycieli i dyrekcję, a realizowany z roku na rok. Uczą się uczestniczenia w wyborach, których reguły są nieprzejrzyste, bycia reprezentowanym przez biernych przedstawicieli niemających ich mandatu" (Napiontek 2013, s. 127). Ten osąd nie jest bynajmniej przesadzony, jest raczej reprezentatywny dla wielu innych wniosków z badań nad polską szkolną rzeczywistością oświatową.

Warto podkreślić kwestię naruszonej równowagi między rywalizacją a współpracą. Nie negując potrzeby kształtowania obu można jednak dostrzec liczne przejawy dominacji rywalizacji nad współpracą - bez niej zaś nie będzie właściwego klimatu dla myślenia w kategoriach dobra wspólnego. Do rywalizacji zaś raczej niż współpracy zmusza powszechna przecież „testomania”, którą sygnalizował zresztą cytowany wyżej Olubiński - a nie zanosi się na odwrót od tej tendencji. Systemy zewnętrznego oceniania, które chyba raczej na trwałe zadomowiły się w naszej oświacie, niejako zmuszają uczniów, ale również nauczycieli, do postawy rywalizacyjnej, nie pozostawiając zbyt dużo miejsca na pracę o bardziej kooperacyjnym charakterze.

Kolejna sprawa to jakość komunikacji między różnymi podmiotami edukacji. Nie rozwijając w tym tekście tego zagadnienia, można śmiało stwierdzić, że - na co wskazują wyniki licznych badań (zob. m.in. Kubiak-Szymborska 2005; Wawrzak-Chodaczek 2007, s. 215-223; Lewandowska-Kidoń 2009, s. 208-217; Opozda 2010, s. 145-156) - w szkolnej, jak również akademickiej, edukacji zamiast dialogu mają raczej miejsce oddzielne monologi nauczycieli (nauczycieli akademickich) i uczniów (studentów), z zasadniczą dominacją monologów nauczycielskich, z niewielkim marginesem dopuszczania do głosu uczniów czy studentów. Można wskazać przede wszystkim takie oto, wciąż obecne w polskim systemie edukacji, praktyki, niesprzyjające komunikacji: 1) przewaga transmisji wiedzy nad jej poszukiwaniem; 2) wdrażanie uczniów w „kulturę milczenia” - dominuje głos nauczyciela, to on definiuje sytuację oraz określa ramy i warunki, w których uczniowie mogą zabrać głos; 3) dążenie przez nauczycieli do triumfu „właściwego” stanowiska np. prawie każda dyskusja na lekcji obowiązkowo kończy się wyprowadzeniem, a częściej narzuceniem przez nauczyciela, wniosków, które muszą zostać zapisane jako notatka $z$ dyskusji i przyjęte przez wszystkich za jedynie prawdziwe i obowiązujące; 4) utożsamianie odmiennego zdania ze złą wolą - wielu nauczycieli 
jest skłonnych traktować sądy uczniów, które stoją w opozycji do ich zdania, jako osobistą zniewagę czy wręcz przejaw agresji pod swoim adresem.

Pewnym potwierdzeniem tych tez są moje liczne rozmowy ze studentami, z których wynika, że większość z nich spotyka się z prawdziwą dyskusją podczas zajęć dopiero na studiach! Podczas nauki w szkołach wszystkich szczebli prawie jej nie zaznali, a jeśli bywała, to najczęściej miewała charakter pozorny, a uczniowie doskonale to wyczuwali i z tego choćby powodu nie traktowali jej poważnie. Oczekiwali dyskusji autentycznych, podczas których wszystkie strony liczą się z wypowiedzianymi zdaniami, a konkluzja jest wypracowywana wspólnie, także w drodze kompromisu, podczas którego zdania uczniów są traktowane na równi ze zdaniem nauczyciela; a jeśli nauczyciel chce, by jego zdanie było ważniejsze od zdania uczniów, by dominowało, by było podstawą podsumowania, to powinien ich przekonać za pomocą argumentów, a nie jedynie „mocą swego urzędu”. Oczekiwali, lecz najczęściej się nie doczekiwali.

Tymczasem właśnie tak prowadzona dyskusja byłaby znakomitą sposobnością nabywania umiejętności koniecznych do wyłaniania się - na drodze otwartej debaty - dobra wspólnego. Jest to ważne tym bardziej, że przeciętny obywatel nie ma skąd czerpać dobrych wzorców debatowania - obserwowane w telewizji „debaty” nader często są tylko propagandowymi spektaklami, silnie uwikłanymi w rozgrywki międzypartyjne, w których nie widać jakichkolwiek oznak troski dyskutantów o dobro wspólne. Tym bardziej więc umiejętność debatowania oraz myślenia w kategoriach dobra wspólnego staje się istotnym wyzwaniem dla edukacji.

\section{LITERATURA}

Albińska E., 2009, Dobro. W: S. Jedynak, J. Kojkoł (red.), Encyklopedia filozofii wychowania. Bydgoszcz, Oficyna Wydawnicza Branta, 54-57.

Buksiński T., 2006, Współczesne filozofie polityki. Poznań, Wydawnictwo UAM.

Czapiński J., 2015, Stan społeczeństwa obywatelskiego. W: J. Czapiński, T. Panek (red.), Diagnoza społeczna 2015. Warunki i jakość życia Polaków. Raport. „Contemporary Economics”, nr 9/4, 332-372, opublikowano: http://www.diagnoza.com/pliki/ raporty/Diagnoza_raport_2015.pdf [dostęp: 16.07.2018].

Dziubka K., Szlachta B., Nijakowski L.N., 2008, Idee i ideologie we wspótczesnym świecie. Warszawa, Wydawnictwo Naukowe PWN.

Koperek J., 2004, Dobro wspólne. W: B. Szlachta (red.), Słownik społeczny. Kraków, Wydawnictwo WAM, 139-147.

Kubiak-Szymborska E., 2005, Nauczyciele akademiccy - studenci. Między partnerstwem a pozorna stycznością. Bydgoszcz, Wydawnictwo Wers. 
Kwieciński Z., 1996, Demokracja w edukacji czy edukacja dla demokracji? W: K. Przyszczypkowski, A. Zandecki (red.), Edukacja i młodzież wobec społeczeństwa obywatelskiego. Poznań-Toruń, Wydawnictwo Edytor, 11-20.

Kwieciński Z., 1998, Demokracja jako wyzwania i zadania edukacyjne. W: Z. Melosik, K. Przyszczypkowski (red.), Wychowanie obywatelskie. Studium teoretyczne, porównawcze i empiryczne. Poznań-Toruń, Wydawnictwo Edytor, 9-33.

Kwieciński Z., 2017, Edukacja publiczna w chybotliwej demokracji: perspektywa pedagogiki krytycznej. „Nauka”, nr 3, 57-70.

Lewandowska-Kidoń T., 2009, Język nietolerancji w polskich szkołach. W: W.J. Maliszewski, I. Nowosad, R. Uździcki (red.), Zarządzanie i komunikacja w sytuacjach szkolnych. Toruń, Wydawnictwo Adam Marszałek, 208-217.

Napiontek O., 2013, Szkoła - przestrzeń obywatelskiego uczestnictwa. W: A. Kordasiewicz, P. Sadura (red.), Edukacja obywatelska $w$ działaniu. Warszawa, Wydawnictwo Naukowe Scholar, 104-127.

O nieufności i zaufaniu. Komunikat CBOS nr 35/2018, 2018, A. Cybulska, K. Pankowski (oprac.), opublikowano: https://www.cbos.pl/SPISKOM.POL/2018/K_035_18.PDF [dostęp: 17.07.2018].

Olubiński A., 2016, Podmiotowa aktywność własna jako szansa samorealizacji i rozwoju ( $w$ świetle założeń edukacji humanistycznej i krytycznej). „Przegląd Pedagogiczny”, nr 2, 33-47.

Opozda D., 2010, Narracje - przemoc - negocjacje: trzy wymiary trójpodmiotowej komunikacji szkolnej w spojrzeniu fenomenologiczno-hermeneutycznym. W: K. Czerwiński, M. Fiedor, J. Kubiczek (red.), Komunikowanie społeczne w edukacji. Zagrożenia podmiotowe i psychospołeczne. Toruń, Wydawnictwo Adam Marszałek, 145-156. Potulicka E., Rutkowiak J., 2012, Neoliberalne uwikłania edukacji. Kraków, Oficyna Wydawnicza Impuls.

Przybyszewski K., 2013, Kultura publiczna. Refleksje wokół kondycji społeczeństwa i państwa polskiego. Poznań, Wydawnictwo Naukowe Instytutu Filozofii UAM.

Sandel M.J., 2013, Sprawiedliwość. Jak postępować słusznie?, tłum. O. Siara. Warszawa, Wydawnictwo Kurhaus.

Słownik socjologii i nauk społecznych, 2005, G. Marshall (red.), Warszawa, Wydawnictwo Naukowe PWN.

Szymczyk J., 2012, Rudymentarne wartości republikańskie. Zarys problematyki. W: J. Szymczyk (red.), Segmenty aktywności społecznej a wartości. Idee i praktyka. Lublin, Wydawnictwo KUL, 111-152.

Śpiewak P., 1998, W stronę wspólnego dobra. Warszawa, Fundacja Aletheia.

Tischner J., 2000, Myślenie według wartości. Kraków, Wydawnictwo Znak.

Wawrzak-Chodaczek M., 2007, Kompetencje komunikacyjne nauczycieli akademickich w kontaktach interpersonalnych ze studentami. W: W.J. Maliszewski (red.), Kompe- 
tencja w porozumiewaniu się nauczyciela akademickiego. Wielorakie perspektywy. Toruń, Wydawnictwo Adam Marszałek, 215-223.

Zaangażowanie Polaków na rzecz społeczności lokalnej. Komunikat CBOS nr 74/2018, 2018, R. Boguszewski (oprac.), opublikowano: https://www.cbos.pl/SPISKOM. POL/2018/K_074_18.PDF [dostęp: 16.07.2018].

\title{
COMMON GOOD AS A PEDAGOGICAL CATEGORY
}

\begin{abstract}
The common good is a category from the area of political philosophy, underestimated by liberalism, and very important for the republican tradition. This category is problematic because there are difficulties with defining it and setting the scope. The author puts forward the thesis that the common good - regardless of the controversy that arouses in political philosophy - is a category important for pedagogical reflection, and at the same time is an absent category. The rationale behind this thesis focuses on two issues: 1) the aims of education are neoliberally oriented and the category of the common good is almost absent in them, which is very undesirable in the context of shaping the citizens of a democratic community; 2) processes taking place inside the education are also not conducive to thinking in terms of the common good, mainly due to the advantage of rivalry over cooperation and faulty interpersonal communication.
\end{abstract}

Keywords: common good, democracy, education, communication 